\title{
THE ACOUSTIC PROPERTIES OF THE SYLLABIC RHOTIC OF CROATIAN
}

\section{Introduction}

Unlike other natural classes of speech sounds, rhotics constitute a group that can hardly be defined according to articulatory or acoustic criteria as members of the category do not seem to share a single property. ${ }^{1}$ In spite of this intriguing fact, in the phonetic literature, rhotics are frequently treated as if their heterogeneity did not have any influence on their phonology. One of the arguments frequently quoted by various authors ${ }^{2}$ states that rhotics typically occupy vowel-adjacent positions within the syllable irrespective of their place and manner of articulation. However, Croatian, Czech, Macedonian, Polish, Russian and Serbian, to mention several examples, constitute exceptions to the rule in that they also allow for sound combinations in which rhotics do not have to be preceded or followed by a vowel.

Importantly, in several Slavic languages, e.g. Croatian, Czech, Macedonian, Slovak, Slovenian, an r-sound that is not adjacent to a vowel is regarded as

* Sylwester Jaworski - doktor nauk humanistycznych z zakresu językoznawstwa, adiunkt w Katedrze Filologii Angielskiej Uniwersytetu Szczecińskiego; e-mail: sylwester.jaworski@, univ.szczecin.pl.

1 P. Ladefoged, I. Maddieson, The Sounds of the World's Languages, Blackwell Publishers, Oxford 1996, p. 215; M. Lindau, The story of /r/, [in:] Phonetic Linguistics: Essays in Honor of Peter Ladefoged, ed. Fromkin V., Academic Press, New York 1985, pp. 157-168.

2 R. Wiese, The unity and variation of (German) /r/, "Etudes and Travaux" 2001 (4), pp. 11-26; R. Wiese, The unity and variation of German /r/, "Zeitschrift fur Dialektologie und Linguistik" 2003, 70, pp. 25-43. 
a peak of sonority or the nucleus of a syllable. ${ }^{3}$ For example, in the Croatian word drvar 'woodcutter' that consists of two syllables, the first r-sound is regarded as a syllabic nucleus, while the word-final rhotic is a consonant. By contrast, in the Polish cognate drwal, the rhotic is a consonant and, consequently, the word is monosyllabic, despite having a phonemic make-up very similar to that of the Croatian word. The question that arises while comparing such pairs is what features make the Croatian rhotic syllabic, and what disqualifies the Polish sound from fulfilling the same phonological role. Since most accounts of syllable structure refer to the concept of sonority, e.g. the Sonority Sequencing Principle ${ }^{4}$ or the Optimal Sonority Distance Principle, ${ }^{5}$ one can assume that the sonority value of syllabic rhotics should be similar to that of vowels, which typically act as nuclei. Alternatively, one can posit the presence of an underlying vocalic element that constitutes an integral part of syllabic consonants including rhotics. What logically follows from the argument is that the Croatian sound should be more sonorous than the Polish rhotic found in positions where it is not adjacent to a vowel. Importantly, the Polish rhotic found in the same phonological environments is usually referred to as obstruentised rhotic. ${ }^{6}$

The primary objective of this study is to present the acoustic characteristics of the Croatian syllabic rhotic and find evidence supporting its vocalic properties. The working hypothesis to be verified by the results presented in section 3.2. is that speakers epenthesise a vocalic element that must be long enough to allow them to place primary stress on the rhotic. Since a vocoid is usually inserted between a plosive and a rhotic in $\mathrm{CrV}$ sound patterns, ${ }^{7}$ it will be further argued that,

3 Obviously, syllabic rhotics are not only found in the Balkans, nor is their distribution restricted to the Slavonic languages. A syllabic 'r-sound' is present in the rhotic varieties of English, such as General American (J. Well, Accents of English, Cambridge University Press, Cambridge 1982). Another example that should be mentioned here is the Berber language, which allows not only for liquids, but for any consonant to function as a syllable nucleus (J. Coleman, The phonetics and phonology of Tashlhiyt Berber and syllabic consonants. "Transactions of the Philological Society" 2001, vol. 99, pp. 29-64).

${ }^{4}$ E. Sievers, Grundzüge der Phonetik, Breitkopf and Hartel, Leipzig 1881.

5 K. Dziubalska-Kołaczyk, Beats-and-Binding Phonology, Peter Lang, Frankfurt am Main, Berlin 2002.

${ }^{6}$ E. Gussmann, The Phonology of Polish, Oxford University Press, Oxford 2007; S. Jaworski, A comparison of Croatian syllabic [r] and Polish obstruentised [r], [in:] New Insights into Slavic Linguistics, eds. J. Witkoś, S. Jaworski, Peter Lang, Frankfurt am Main 2014, pp. 179-192.

7 D. Recasens, A. Espinosa, Phonetic typology and positional allophones for alveolar rhotics in Catalan, "Phonetica" 2007, 63, pp. 1-28; M. Baltazani, Acoustic characterization of 
in the case of syllabic rhotics, the duration of the vocalic element should differ substantially from that of the vocoid occurring in $\mathrm{CrV}$ sequences.

The paper is structured as follows. Section 2 presents the natural class of rhotics and it also includes an outline of the history of the syllabic rhotic of Croatian. Section 3 describes the data collection method and presents the most important findings of the study. The final section discusses the results produced by the informants.

\section{Rhotics as a natural class of speech sounds}

Rhotics have intrigued phoneticians due to their articulatory complexity, diversity of articulation and susceptibility to changes over time. Unlike other natural classes, e.g. plosives or fricatives, rhotics constitute a heterogeneous group as their acoustic and articulatory characteristics differ considerably from sound to sound. Common r-sounds found in the world's languages include trills, taps, fricatives and approximants produced in the dental/alveolar and velar/uvular places of articulation. ${ }^{8}$ So diverse is the class of rhotics that Ladefoged and Maddieson ${ }^{9}$ conclude that the only thing they seem to have in common is that they are represented by the grapheme $<r>$ in those languages that use the Latin alphabet.

Table 1 presents common rhotics found in the world's languages. One surprising fact about the list is that it does not include any fricatives, although they are relatively frequent, e.g. some accents of German and French have voiced and voiceless uvular fricative rhotics, represented by the symbols $[\mathrm{r}]$ and $[\chi]$

the Greek rhotic in clusters, "Proceedings of the 18th International Symposium on Theoretical and Applied Linguistics" 2009, 1, pp. 87-95; C.-F. Savu, An acoustic-phonetic perspective on the phonological behaviour of the rhotic tap, "Proceedings of ConSOLE XX" 2012, pp. 213-227.

8 The Kele and Titan languages of Papua New Guinea have the bilabial trill [B] in their sound inventory; however, many authors, e.g. Ladefoged and Maddieson (1996), do not include the sound in the class of rhotics despite its sharing crucial articulatory properties with $[\mathrm{r}]$ and $[\mathrm{R}]$. The tap [r] also constitutes a taxonomic problem as in many languages, e.g. American English, it is an allophonic variant of /t/ and /d/ and, for this reason, should rather be excluded from the class of rhotics.

9 P. Ladefoged, I. Maddieson, The Sounds of the World's Languages, Blackwell Publishers, Oxford 1996, p. 215. 
respectively. ${ }^{10}$ Probably, one reason for excluding them from Ladefoged and Maddieson's (1996) list is that their phonological status is rather uncertain as "[b]oth voiced [в] and voicelss $[\chi]$ are often just fricatives, but sometimes these very sounds are treated as rhotics, as in German or French". ${ }^{11}$

Table 1. Common rhotics (after Ladefoged and Maddieson 1996: 216)

\begin{tabular}{|c|l|}
\hline IPA symbol & \multicolumn{1}{|c|}{ Place and manner of articulation } \\
\hline r & Dental or alveolar trill \\
\hline r & Dental or alveolar tap \\
\hline I & Dental or alveolar approximant \\
\hline r & Post-alveolar flap \\
\hline I & Post-alveolar approximant \\
\hline R & Uvular trill \\
\hline B & Uvular approximant \\
\hline I & Dental or alveolar lateral flap \\
\hline
\end{tabular}

To date, linguists have been unable to define the class of rhotics in articulatory terms, i.e. ones that involve place and manner of articulation, nor have they been able to establish an acoustic feature that would unify rhotics as a natural class. ${ }^{12}$ One acoustic property shared by several types of rhotics is a lowered $\mathrm{F} 3$, but uvular r-sounds have a relatively high third formant and so do dentals. ${ }^{13}$ After examining the characteristics of rhotics, Lindau concludes that "there is no physical property that constitutes the essence of all rhotics". ${ }^{14}$

One solution to the taxonomic problem has been proposed by Wiese ${ }^{15}$ who suggests that they rather be defined on phonotactic grounds as, in all languages that have rhotic segments, the sounds occupy vowel-adjacent positions regardless of the actual manner of articulation. The author further argues that, since the manner of articulation of a rhotic does not seem to affect its phonotactics, all

${ }^{10}$ R. Wiese, op.cit., pp. 11-26; R. Wiese, The unity and variation of German /r/, "Zeitschrift fur Dialektologie und Linguistik" 2003, 70, pp. 25-43.

${ }^{11}$ R. Wiese, The unity and variation of (German) /r/, "Etudes and Travaux" 2001 (4), p. 12.

${ }^{12}$ P. Ladefoged, I. Maddieson, The Sounds of the World's Languages, Blackwell Publishers, Oxford 1996, p. 215.

${ }^{13}$ M. Lindau, The story of /r/, [in:] Phonetic Linguistics: Essays in Honor of Peter Ladefoged, ed. V. Fromkin, Academic Press, New York 1985, p. 165.

${ }^{14}$ M. Lindau, op.cit., p. 166.

${ }^{15} \mathrm{R}$. Wiese, The unity and variation of German /r/, "Zeitschrift fur Dialektologie und Linguistik" 2003, 70, pp. 25-43. 
r-sounds should be regarded as a point on the sonority scale placed between laterals and vowels. However, it should be borne in mind there are also languages, e.g. Berber, ${ }^{16}$ whose phonotactics allows for sound patterns in which rhotics are neither preceded nor followed by a vowel. Such sound combinations are relatively common in the Slavic languages, several of which, Croatian, Czech, Macedonian, Polish, Russian, Slovak and Slovene, ${ }^{17}$ have sound combinations in which rhotics are non-vowel-adjacent. Interestingly, in Croatian, Czech, Macedonian, Slovak and Slovene, r-sounds found in such an environment are said to constitute the syllable nucleus ${ }^{18}$ The acoustic features of one such sound, namely the syllabic rhotic of the Croatian language, are the focus of the following sections.

\subsection{Diachronic changes of rhotics in the Slavic languages}

Croatian belongs to the Slavic branch of the Indo-European language family. More accurately, together with Slovene, Serbian, Macedonian and Bulgarian, it belongs to the so-called South Group of the Slavonic languages. Like any other language, Present Day Croatian is the result of numerous sound changes that have taken place at different stages of its evolution and that have altered its phonology to a greater or lesser extent. Since most of the interesting aspects of the history of the Slavic languages are far beyond the scope of the paper, our discussion of the diachronic changes in the phonology of the Slavic languages, and Croatian in particular, will be restricted to those aspects that determined the development of rhotic segments.

In the phonology of the hypothesised Proto Indo-European language, the sonants [ $\mathrm{m} \mathrm{n} 1 \mathrm{r}]$ are said to have played an important role. Not only did they function as consonants when preceded or followed by a vowel, but they also constituted the second element of diphthongs and, finally, they frequently occurred as syllabic nuclei. ${ }^{19}$ As for the liquids $\left[\mathrm{r}\right.$ l] ${ }_{1}$, they served the function of a nucleus

${ }^{16} \mathrm{~J}$. Coleman, The phonetics and phonology of Tashlhiyt Berber and syllabic consonants, "Transactions of the Philological Society" 2001, 99, pp. 29-64.

${ }^{17}$ Upper Sorbian also has word-final, post-consonantal rhotics as in bratr 'brother'.

${ }^{18}$ Naturally, other languages also allow for syllabic rhotics. For instance, in American English, in the word professor, normally pronounced [рıә' fes. I], the final rhotic is also syllabic.

${ }^{19}$ G. Shevelov, A Prehistory of Slavic. The Historical Phonology of Common Slavic, Universitätsverlag Carl Winter, Heidelberg 1964; L. Moszyński, Wstęp do filologii stowiańskiej, 
and, within the word, they were usually flanked by consonants. ${ }^{20}$ Interestingly, these syllabic liquids had a short and long variant. The rise of the long variant is attributed to vowel gradation, i.e. alterations affecting the quantity of the vowel element of a diphthong, which involved three grades, namely normal, long and zero. In the normal grade, the vowel was short. In the long grade, as the name implies, the vowel was long, whereas, in the zero grade the vocalic element was dropped and syllabicity was transferred to the following glide, sonant or a laryngeal. ${ }^{21}$

The oppositions between syllabic and non-syllabic sonants are thought to have disappeared during the Proto-Baltic period (approximately from 2,000 BC to 1,500 BC). Moszyński (1984) explains that these syllabic segments exhibited a strong tendency towards being pronounced as a sequence of a high vowel, either [i] or [u], and a sonant, which gradually resulted in the elimination of $\left[r_{1} 1 m_{1} n\right]$ from the phoneme inventory as they started to be pronounced as diphthongs. ${ }^{22}$

The Common Slavonic (CS) era, which probably started around 2,000 BC and lasted till $1000 \mathrm{AD}$, can be divided into two periods, namely Early Common Slavonic (ECS) and Late Common Slavonic (LCS). ${ }^{23}$ During the former, one variety of the Slavonic language is said to have been spoken all over the Slavic area, while LCS witnessed a number of significant changes that, in the course of time, gave rise to a number of mutually unintelligible languages. An event that marked the beginning of the end of CS, began in the sixth century AD when the Slavs started migrating to other areas of Europe. ${ }^{24}$ Since various groups of Slavs were no longer able to maintain regular contacts with Slavs living in remote parts of Europe, certain phonological processes affecting Common Slavonic produced different outputs in different regions. ${ }^{25}$

Państwowe Wydawnictwa Naukowe, Warszawa 1984; L. Carlton, Introduction to the Phonological History of the Slavic Languages, Slavica Publishers, Inc., Columbus (Ohio) 1990.

${ }^{20}$ G. Shevelov, op.cit.; L. Moszyński, op.cit.

${ }^{21}$ L. Carlton, op.cit.

${ }^{22}$ A. Schenker, Proto-Slavonic, [in:] The Slavonic Languages, eds. B. Comrie, G. Corbett, New York: Routledge, London 1993, pp. 60-123; Z. Stieber, Zarys gramatyki porównawczej języków słowiańskich, Wydawnictwo Naukowe PWN, Warszawa (1979) 2005.

${ }^{23}$ G. Shevelov, op.cit.

${ }^{24}$ A. Schenker, op.cit., pp. 60-123; C.E. Townsend, L. Janda, Common and Comparative Slavic: Phonetics and Phonology, Slavica Publishers Inc., Columbus 1996.

${ }^{25}$ L. Moszyński, Wstęp do filologii słowiańskiej, Państwowe Wydawnictwa Naukowe, Warszawa 1984; Z. Stieber, Zarys gramatyki porównawczej języków słowiańskich, Wydawnictwo Naukowe PWN, Warszawa (1979) 2005. 
ECS inherited only one rhotic sound from the Proto-Baltic era and it can be assumed with a considerable degree of probability that it was a dental/alveolar trill. ${ }^{26}$ However, in the following LCS period, the sound was affected by various phonological processes. The development that merits particular attention is the change that affected the *tbrt and *tbrt sequences. which are said to have been functional diphthongs. ${ }^{27}$ During the LCS period, in such environments, the diphthongs underwent monophthongisation, as a consequence of which *tbrt and *tbrt started to be pronounced with a syllabic [r] or [1] . Predictably, this development produced different outputs in different dialectal areas of the Slavic world; ${ }^{28}$ however, in the South Slavic languages, the change resulted in the emergence of syllabic liquids.

The *trbt and trbt sound patterns, on the other hand, underwent a slightly more complicated change in that it depended on whether the jer was strong or weak..$^{29}$ Deletion of the front jer $[\mathrm{b}]$ yielded a syllabic palatalised sonant, either $\left[{ }_{\mathrm{j}}^{\mathrm{j}}\right]$ or $\left[\mathrm{r}_{\mathrm{r}}^{\mathrm{r}}\right]$, whereas elision of the back jer [b], gave rise to a plain syllabic liquid, either $[1]$ or $[\mathrm{r}] . .^{30}$

There is evidence strongly suggesting that the plain and palatalised variants of the syllabic lateral were still phonemic in Old Church Slavonic (OCS), spoken between the mid ninth century till the end of the eleventh century, while $[\mathrm{r}]$ and $\left[\mathrm{r}^{\mathrm{r}}\right]$ had merged into $[\mathrm{r}]$ by that time, ${ }^{31}$ and since then, the status of the syllabic rhotic has not changed.

This very brief outline of the phonological history of the syllabic rhotic of Croatian shows clearly that, diachronically speaking, the sound is rather unstable in that, at different stages of development, it either appeared in or disappeared from the sound system of the language. Given the tendency to change exhibited by the sound, one cannot exclude the possibility that, in the future, the sound will lose its syllabic status once again.

${ }^{26}$ Z. Stieber, op.cit.

${ }^{27}$ It is conventional in Slavic linguistics to the grapheme $<\mathrm{t}>$ to represent any obstruent, while $<\mathrm{r}>$ stands for any liquid.

${ }^{28}$ Argues that syllabic liquids never occurred in the languages of the East Slavic Group, i.e. Russian, Belorussian and Ukrainian. See Stieber, op.cit., pp. 34.

${ }^{29}$ L. Carlton, Introduction to the Phonological History of the Slavic Languages, Slavica Publishers, Inc., Columbus (Ohio) 1990, p. 153.

${ }^{30}$ The jers [b] and [ъ] evolved from Proto-Slavonic short [i] and [u], respectively.

${ }^{31}$ D. Huntley, Old Church Slavonic, [in:] The Slavonic Languages, eds. B. Comrie, G. Corbett, Routledge, London 1993, pp. 125-186. 


\subsubsection{The syllabic rhotic of contemporary Croatian}

In Croatian phonology, the rhotic is classified as an apical alveolar trill, ${ }^{32}$ although there is a considerable amount of phonetic variation that seems to stem from the inherent articulatory complexity of the sound (see section 3.3). The Croatian [r] has two major variants, namely syllabic and non-syllabic. The former is never vowel adjacent, while the latter occurs pre-vocalically, post-vocalically or intervocalically. The phonological environments in which the two variants appear are presented in (1).

$$
\begin{aligned}
& / \mathrm{r} / \rightarrow[\mathrm{r}] / \mathrm{C}_{-} \mathrm{C}, \mathrm{H}_{-} \mathrm{C} \\
& / \mathrm{r} / \rightarrow[\mathrm{r}] / \mathrm{V}_{-} \mathrm{V}, \mathrm{V}_{-},{ }_{-} \mathrm{V}
\end{aligned}
$$

It is assumed that the two variants do not differ in terms of articulation; however, such a claim is rather debatable as in other languages rhotics that are not adjacent to vowels are not regarded as syllabic. For instance, in the Polish word $r d z a$ [rdza] 'rust', the rhotic is not regarded as a vowel despite being placed in exactly the same environment as in the Croatian cognate $r d a$, phonemically /rdza/. The analysis of Croatian words containing syllabic and non-syllabic ones presented in section 3 is meant to cast more light on the acoustic properties of the syllabic rhotics of the language.

\section{The aim of the study}

This study is an attempt at establishing whether the syllabic status of the Croatian rhotic should be attributed to its extraordinary articulatory properties or, alternatively, to the vocalic element that usually occurs in $\mathrm{CrC}$ sound patterns. The working hypothesis put forward in the paper is that, in the case of syllabic rhotics, speakers epenthesise a vowel whose duration is sufficient to make an audible change of pitch over it, which is necessary if a syllable with a rhotic nucleus is to be perceived as accented.

${ }^{32}$ A. Ščukanec, Glas r u hrvatskome, njemačkome i engleskome jeziku, "LAHOR: časopis za hrvatski kao materinski, drugi i strani jezik" 2008, 1 (5), pp. 66-79. 


\subsection{Subjects and procedure}

In order to determine the acoustic properties of the Croatian rhotic, five native speakers of the language were asked to read twice a randomised list of words embedded in the carrier phrase Napisala je X na ploču 'She wrote X on the board'. All the informants are in their early twenties, they were born and brought up in the Rijeka region and they do not have any speech impediments. The participants are students of the Department of English at Rijeka University and volunteered to take part in the experiment. Naturally, were nad've as to the objectives of the study.

The phonological contexts in which the rhotic was found included the three environments presented in (2). Given the objectives of the paper, the contrast in the duration of the hypothesized epenthetic vowel in CorC and CorV sequences is of particular interest.

$$
\begin{aligned}
& \text { \#rC - onset-initial, pre-consonantal, e.g. rđa 'rust' [rđ̄za] } \\
& \# \mathrm{CrC} \text { - onset medial, inter-consonantal, e.g. brdo 'mountain' [brdo] } \\
& \# \mathrm{CrV} \text { - onset final, pre-vocalic, e.g. grad 'town' [grad] }
\end{aligned}
$$

The recording session took place in the Department's premises in April, 2013. The Praat software (version 4.2.21) was used to make the recordings, digitise the data and make the measurements. The first two formant frequencies (F1 and F2), necessary to determine the quality of each vowel, were measured manually. In the rare cases of vowels that had a steady state, F1 and F2 were measured at midpoint. However, in most cases the formants were not stable; therefore, measurements were taken at the peak of F1. The rationale behind the procedure is that the points of measurement correspond to the lowest position of the articulating part of the tongue that can be thought of as the articulatory target.

\subsection{Results and discussion}

The first conclusion that can be drawn from the data is that the Croatian rhotic has three distinct phonetic realisations, namely tap, fricative and approximant. As tapped variants predominate in both contexts ( $81 \%$ of all tokens), it can be assumed that they constitute the articulatory target. Tapped variants predomi- 
nate (97\%) when the rhotic, be it word-initial or interconsonantal, is followed by a plosive, as in $r t$ 'cape' or krk 'neck'. On the other hand, when followed by a sibilant fricative or affricate, e.g. in bršljan 'ivy' or krčma 'tavern', the rhotic manifests a strong tendency towards frication. In the data, all the tokens were fricated in such contexts. This finding is by no means surprising as a similar phenomenon has been attested in other languages. For instance, Blecua provides acoustic data strongly suggesting that the manner of articulation of the Spanish tap / $/$ / depends primarily on the manner of articulation of the following consonant. ${ }^{33}$ Frication also appears to be influenced, at least to some extent, by the quality of the adjacent vowel(s). Jaworski and Gillian's (2011) data indicate that, in Polish, intervocalic rhotics undergo frication more frequently if the flanking vowels are high and front than in those contexts where the neighbouring vowels are non-high and back. ${ }^{34}$
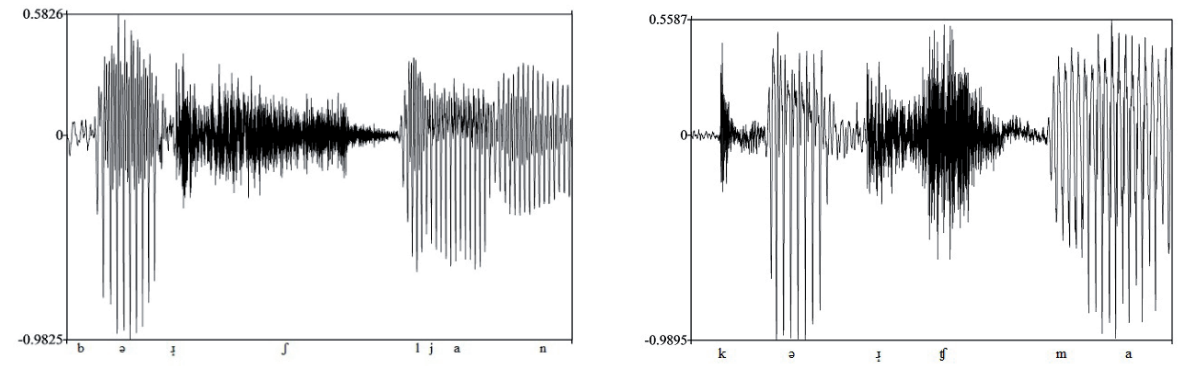

Figure 1. Partially fricated rhotics in bršljan 'ivy' and krčma 'tavern'

Figure 1 shows the fricated realizations of the r-sound in bršljan 'ivy' and krčma 'tavern'. In both cases, the informants managed to produce a complete closure for the tap which was later gradually released into the following segment. One noticeable consequence of frication is the absence of a vocalic interval separating the rhotic from the following consonant.

${ }^{33}$ B. Blecua, Las vibrantes del Espańol: manifestaciones acústicas y procesos fonéticos, Unpublished PhD dissertation, Universidad Autonoma de Barcelona, Barcelona 2001.

${ }^{34}$ S. Jaworski, E. Gillian, On the phonetic instability of the Polish rhotic /r/, "Poznań Studies in Contemporary Linguistics" 2011, 47 (2), pp. 380-398. 
Word-initial syllabic rhotics also follow this pattern as illustrated in Figure 2 that depicts the word $r d a$ 'rust' in which the tap is flanked by two vocoids. ${ }^{35}$ Two vocalic elements normally occur when the tap is followed by a plosive, but an affricate or a fricative can affect the manner of articulation of the preceding rhotic that regularly undergoes reduction to either a fricative or an approximant as shown in the right hand panel of Figure 2. Interestingly, in both cases, the onset of the first vocalic element was reinforced glottally. This phenomenon regularly takes place when a word-initial syllabic rhotic is produced after a pause; however, in our study the target words were embedded in the carrier phrase Napisala je $X$ na ploču and many of the vocoids preceding syllabic rhotics in the \# $\mathrm{rC}$ enviroment coalesce with the vowel of $j e$, thus determining their duration with an acceptable degree of accuracy is rather impossible.
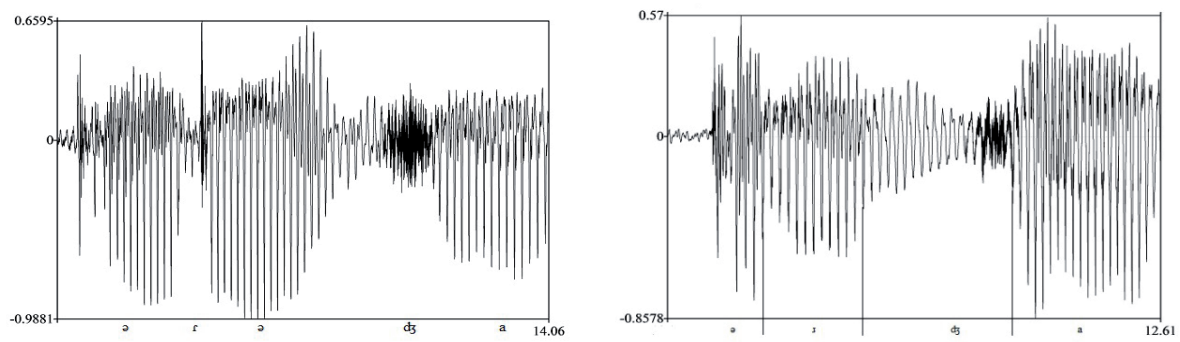

Figure 2. Tap and approximant realisations of the rhotic in rđa 'rust'

Inter-consonantal syllabic rhotics are not totally resistant to phonetic change as their actual realisation also depends on the manner of articulation of the neighbouring consonants. As in the case of word-initial rhotics, if a $[\mathrm{r}]$ sound is flanked by two plosives, it is usually realised as a tap and, in the majority of cases, there are usually two distinct vocalic intervals separating the tap from the plosives (but see the spectrogram of grgeč in Figure 3), while a neighbouring fricative or affricate results in fricating the rhotic (see Figure 4).

As for the relative duration of the epenthetic vowels, they occur on both sides of syllabic rhotics, the recorded material analysed for the purposes of the paper does not provide a clear answer as a large amount of inter- and intra-speaker variation has been observed. The two spectrograms in Figure 3 show that the post-rhotic vocalic element can undergo deletion as in this realisation of grge ̌

${ }^{35}$ Since the vocalic elements tend to be central vowels of undetermined quality (see section 4.2.1.), the phonetic symbol that stands for the schwa sound will be used here for convenience. 
'bass' or it can be longer than the pre-rhotic epenthetic vowel. Still, in a majority of cases, the preceding vocoid is longer and more salient that the other.

On the other hand, the data strongly suggest that vocalic intervals, especially the first one, are considerably longer when a syllabic rhotic is preceded by a plosive than by a fricative. The two spectrograms in Figure 3 show that the vocalic element in grgec is almost twice as long as that of frka, 51 and $18 \mathrm{~ms}$. respectively. Although the data produced by all subjects follow this pattern, the number of tokens that could be compared in this regard is not sufficient to draw far-reaching conclusions; therefore, more extensive research is necessary to confirm the finding.
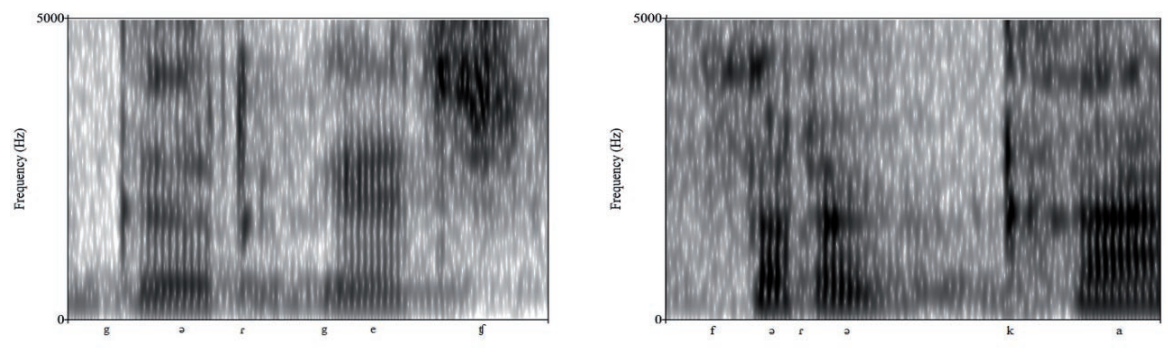

Figure 3. The duration of epenthetic vowels in grgeč and frka

Given the objectives of the paper, it is crucial to provide acoustic evidence confirming the special phonological status of syllabic rhotics. In order to achieve the goal, the epenthetic vowels preceding syllabic rhotics and those found between a consonant and non-syllabic rhotic, e.g. in brdo 'mountain' and brada 'beard', were measured and compared in regard to duration. The obtained results indicate unequivocally that syllabic rhotics are preceded by markedly longer vocalic elements. Figure 4 depicts spectrograms of the two words in which the vocalic segment between the bilabial plosive and the non-syllabic rhotic is only $28 \mathrm{~ms}$ long, whereas in the other word, the [ə] sound is more than twice as long (63 ms).

Although, in most cases, the differences in duration between the two types of epenthetic vowel are not as striking as in Figure 4, the data obtained from the five informants consistently follow the pattern. Further evidence substantiating the claim comes from a statistical test which reveals that, for each participant, the differences in duration are highly significant (see Table 2). 

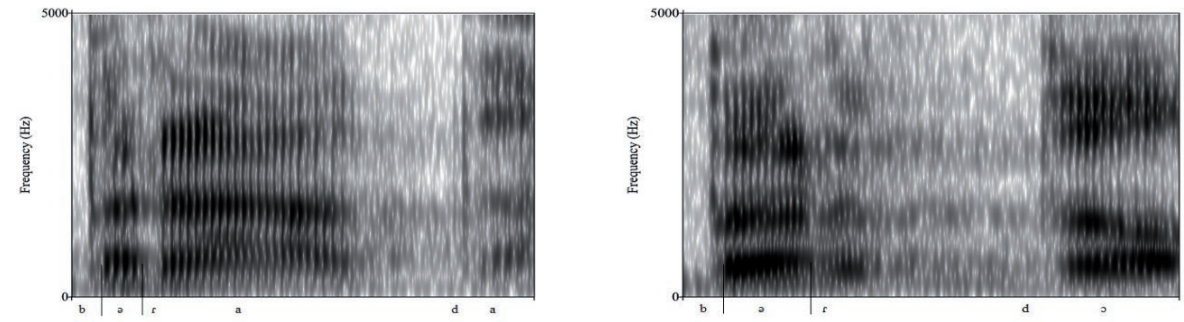

Figure 4. Duration of epenthetic vowels in brada 'beard' and brdo 'mountain'

Table 2. Duration of epenthetic vowels preceding syllabic and non-syllabic rhotics

\begin{tabular}{|l|c|c|c|c|c|}
\hline Phonological context & Speaker 1 & Speaker 2 & Speaker 3 & Speaker 4 & Speaker 5 \\
\hline CrC, e.g. brdo 'hill' & $30.53( \pm 10.1)$ & $38.38( \pm 9.1)$ & $50( \pm 13.4)$ & $45.17( \pm 8.3)$ & $37.95( \pm 9.3)$ \\
\hline CrV, e.g. brada 'beard' & $22.33( \pm 8.42)$ & $23.68( \pm 6.69)$ & $28.93( \pm 9.72)$ & $26.11( \pm 11.2)$ & $27.72( \pm 7.1)$ \\
\hline Statistical significance & $\mathrm{p}<0.0001$ & $\mathrm{p}<0.00001$ & $\mathrm{p}<0.00001$ & $\mathrm{p}<0.00001$ & $\mathrm{p}<0.00001$ \\
\hline
\end{tabular}

As the data in Table 2 show, the duration of the epenthetic vowel differs substantially from speaker to speaker. For instance, a comparison of Speaker's 3 epenthetic vowels with those produced by any other informant yields statistically significant results $(\mathrm{p}<0.05)$. On the other hand, the vocalic elements articulated by Speakers 2 and 5 are rather similar; therefore, in their case, a statistical test did not produce significant results.

\subsubsection{The acoustic properties of the vocalic elements}

The formant values of the vocalic elements indicate that it should be classified as a mid central vowel that, for the sake of convenience, will be referred to as schwa and represented by the phonetic symbol [ə] despite the fact that its acoustic parameters, mean F1 $=613 \mathrm{~Hz}, \mathrm{~F} 2=1497 \mathrm{~Hz}$, differ to some extent from those of the canonical schwa sound as described in Ladefoged (2006). ${ }^{36}$ Figure 5 presents a scatterplot based on 40 tokens of [i], [a], [u] and [ə] produced by Speaker 1, which proves that, indeed, the epenthetic [ə] sound is higher and slightly more central than unaccented [a]. Despite a certain degree of overlap, the differences between the first and second formants turned out to be statistically

${ }^{36}$ P. Ladefoged, A Course in Phonetics, Thomson Wardsworth, Boston 2006. 
significant in the case of F2 ( $\mathrm{p}=0.0069)$, and highly significant as far as F1 is concerned $(\mathrm{p}<0.00001)$.

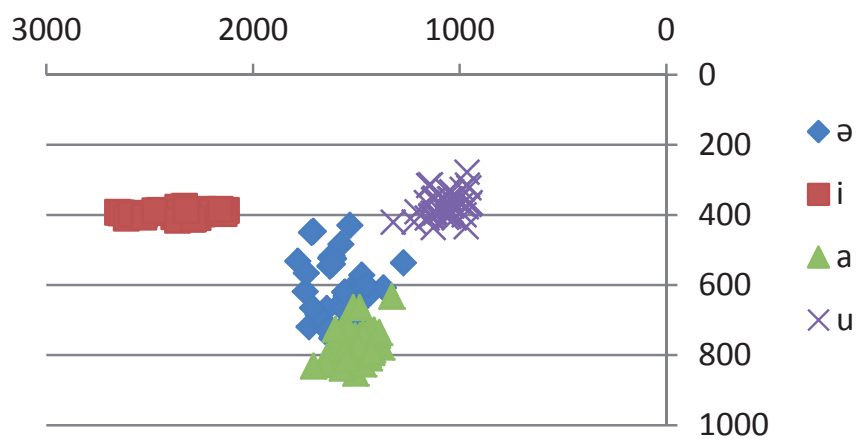

Figure 5. Formant values of [i], [a], [u] and [ə] produced by Speaker 1

The mean F1 and F2 values of the four vowels shown in Table 3 indicate that, while articulating syllabic rhotics, all the subjects produced an epenthetic schwa-like sound whose distribution in the vowel space resembles the one presented in Figure 5 in that [ə] in all cases is significantly higher and more advanced than the [a] sound.

Table 3. Mean F1 and F2 values of [i], [u], [a] and [ə] produced by the five subjects

\begin{tabular}{|c|c|c|c|c|c|c|c|c|c|c|}
\hline & \multicolumn{2}{|c|}{ Speaker 1 } & \multicolumn{2}{c|}{ Speaker 2 } & \multicolumn{2}{c|}{ Speaker 3 } & \multicolumn{2}{c|}{ Speaker 4 } & \multicolumn{2}{c|}{ Speaker 5 } \\
\cline { 2 - 11 } & $\mathrm{F} 1$ & $\mathrm{~F} 2$ & $\mathrm{~F} 1$ & $\mathrm{~F} 2$ & $\mathrm{~F} 1$ & $\mathrm{~F} 2$ & $\mathrm{~F} 1$ & $\mathrm{~F} 2$ & $\mathrm{~F} 1$ & $\mathrm{~F} 2$ \\
\hline$[\mathrm{i}]$ & 396 & 2360 & 392 & 2157 & 376 & 2446 & 393 & 2464 & 377 & 2397 \\
& $( \pm 12)$ & $( \pm 135)$ & $( \pm 25)$ & $( \pm 67)$ & $( \pm 29)$ & $( \pm 57)$ & $( \pm 25)$ & $( \pm 108)$ & $( \pm 19)$ & $( \pm 69)$ \\
\hline$[\mathrm{u}]$ & 374 & 1068 & 406 & 1132 & 393 & 1054 & 439 & 1042 & 412 & 1024 \\
& $( \pm 37)$ & $( \pm 86)$ & $( \pm 47)$ & $( \pm 48)$ & $( \pm 36)$ & $( \pm 49)$ & $( \pm 23)$ & $( \pm 63)$ & $( \pm 27)$ & $( \pm 59)$ \\
\hline$[\mathrm{a}]$ & 766 & 1497 & 740 & 1482 & 828 & 1548 & 726 & 1453 & 744 & 1487 \\
& $( \pm 48)$ & $( \pm 81)$ & $( \pm 52)$ & $( \pm 139)$ & $( \pm 41)$ & $( \pm 67)$ & $( \pm 29)$ & $( \pm 63)$ & $( \pm 23)$ & $( \pm 48)$ \\
\hline$[ə]$ & 613 & 1576 & 533 & 1625 & 602 & 1746 & 569 & 1765 & 515 & 1593 \\
& $( \pm 83)$ & $( \pm 111)$ & $( \pm 42)$ & $( \pm 137)$ & $( \pm 69)$ & $( \pm 86)$ & $( \pm 57)$ & $( \pm 87)$ & $( \pm 39)$ & $( \pm 93)$ \\
\hline
\end{tabular}

The duration of the epenthetic vowel is another parameter that was investigated. A comparison of its length with that of the other vowels in the carrier phrase has revealed that, in some cases, the vocoids are actually longer than unaccented vowels. Figure 6 shows the duration of all the vowels in the carrier phrase and the two epenthetic vowels flanking the syllabic rhotic in the word $g r b$ 'emblem' produced by Speaker 2. Since grb is a monosyllabic word, the rhotic 
bears primary stress, which must have affected its duration, or rather the duration of the epenthetic vowels on both sides of the tap. Somewhat surprisingly, the duration of the first vocalic element turned out to be greater than that of some unaccented vowels. Figure 6 also illustrates the general tendency for the first epenthetic vocalic element to be longer than the other in the $\mathrm{CrC}$ context.

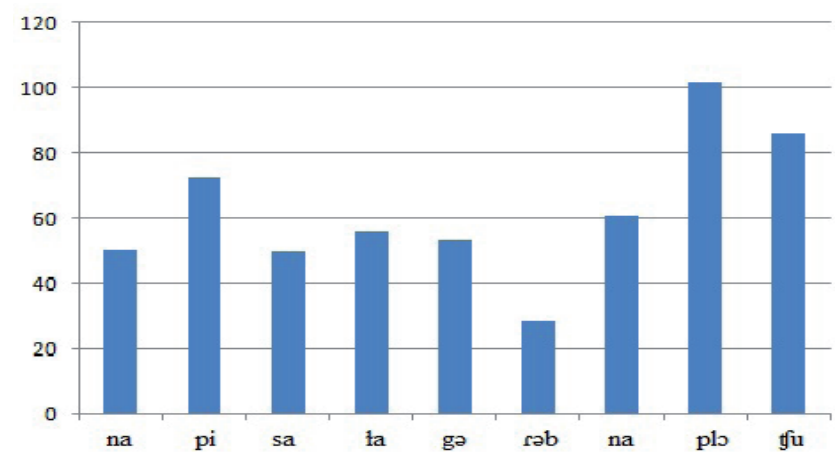

Figure 6. Duration of all vowels in the sentence Napisala je grb na ploču produced by Speaker 1

As the obstruent part of the rhotic can be realised in several ways, the comparison of the duration of pre- and post-rhotic vocoids will be based on those target words in which the participants produced two epenthetic vowels. The target words in which a syllabic rhotic is followed by a lateral, nasal, fricative or an affricate were excluded due to the lack of a vocoid sound. The data in Table 4 prove that, indeed, the pre-rhotic vocalic element is considerably longer than the post-rhotic one as in all cases the difference in duration is statistically significant and in two cases it is highly significant. However, on no account should it be assumed that the former is always longer than the latter.

Table 4. Duration of the pre-rhotic and post-rhotic epenthetic vowels in Croatian

\begin{tabular}{|c|c|c|c|c|c|c|c|c|c|c|}
\hline Speaker & \multicolumn{2}{|c|}{ Speaker 1} & \multicolumn{2}{|c|}{ Speaker 2} & \multicolumn{2}{|c|}{ Speaker 3} & \multicolumn{2}{|c|}{ Speaker 4} & \multicolumn{2}{|c|}{ Speaker 5} \\
\hline Context & CorC & CrəC & CorC & $\mathrm{Cr} \partial \mathrm{C}$ & CorC & CrəC & CorC & $\mathrm{Cr \partial C}$ & CorC & $\mathrm{Cr} \partial \mathrm{C}$ \\
\hline Mean & 40.18 & 27.45 & 26.73 & 22.5 & 34.94 & 28.06 & 49.90 & 31.81 & 42.41 & 27.18 \\
\hline SD & 9.61 & 7.1 & 7.11 & 5.44 & 9.55 & 6.24 & 14.64 & 11.43 & 7.99 & 7.69 \\
\hline p level & \multicolumn{2}{|c|}{$\mathrm{p}<0.00001$} & \multicolumn{2}{|c|}{$\mathrm{p}=0.0309$} & \multicolumn{2}{|c|}{$p=0.015$} & \multicolumn{2}{|c|}{$p=0.001$} & \multicolumn{2}{|c|}{$\mathrm{p}<0.00001$} \\
\hline $\begin{array}{l}\text { No. of } \\
\text { tokens }\end{array}$ & \multicolumn{2}{|c|}{46} & \multicolumn{2}{|c|}{44} & \multicolumn{2}{|c|}{36} & \multicolumn{2}{|c|}{42} & \multicolumn{2}{|c|}{46} \\
\hline
\end{tabular}


The data presented in this paper allow one to formulate a rather controversial claim that the Croatian language does not have a syllabic rhotic. At least two arguments can be quoted to substantiate the claim. Most importantly, the epenthetic vowel is sufficiently long to be regarded as a full vowel. As a matter of fact, foreigners exposed to Croatian hear a distinct vowel in words such as krk 'neck' and, depending on their mother language, identify it either as [i] or [ə]. Furthermore, in languages whose phonotactics also allows for $\mathrm{CrC}$ sound patterns with a non-syllabic rhotic, e.g. Polish, the epenthetic vowel is considerably shorter. ${ }^{37}$

Another scenario that cannot be rejected out of hand is that sound change is taking place. That is why it would be very interesting to examine old recordings and compare the duration of the epenthetic vowel in Croatian spoken at the beginning of the previous century with that of contemporary Croatian. If it has become longer, it would obviously mean that the Croatian sound is undergoing yet another shift from a syllabic to a non-syllabic realisation, as it did in the past (see section 2.2).

\section{Conclusion}

The Croatian rhotic, usually realised as a tap, is a rather uncommon sound as it functions as the nucleus of the syllable in all those words where it is not adjacent to a vowel. The data collected and examined by the present author indicate that, in such words, the rhotic consists of two parts, namely an epenthetic vowel and a tap. Importantly, this vocoid turns out to be substantially longer than the one found between a consonant and a rhotic in $\mathrm{CrV}$ sound combinations. That is the reason why some researchers,$^{38}$ distinguish between the two vocoids and they use the term epenthetic vowel to refer to the former, while the latter sound is labelled an intrusive vowel.

Since epenthetic vowels have been found to be significantly longer than intrusive vowels, it can be assumed that the vowel-like properties of the syllabic rhotic should be attributed to the vocalic element(s), rather than to the tap, as they

${ }^{37}$ S. Jaworski, A comparison of Croatian syllabic [r] and Polish obstruentised [r], [in:] New Insights into Slavic Linguistics, ed. J. Witkoś, S. Jaworski, Peter Lang, Frankfurt am Main 2014, pp. 179-192.

${ }^{38}$ C.-F. Savu, An acoustic-phonetic perspective on the phonological behaviour of the rhotic tap, "Proceedings of ConSOLE" XX, 2012, pp. 213-227. 
enable speakers to make pitch changes and length distinctions. Consequently, such vocoids should be regarded as parts of the rhotic's internal structure.

The results presented in the paper raise a number of questions that should be addressed in follow-up studies. For instance, one should determine the extent to which the epenthetic segment undergoes reduction in spontaneous speech. Next, it would be interesting to see whether syllabic rhotics in other languages, e.g. Slovene and Macedonian, have similar acoustic properties and undergo similar changes in connected speech. Also, it should be established whether the quality and duration of the epenthetic vowel depend on the place of articulation of the preceding or following consonant. Finally, a comparison of recordings made approximately a century ago with recordings of contemporary Croatian would provide objective evidence as to whether or not the syllabic rhotic of Croatian is undergoing change.

\section{References}

Baltazani M., 2009, Acoustic characterization of the Greek rhotic in clusters, "Proceedings of the 18th International Symposium on Theoretical and Applied Linguistics" 1, pp. 87-95.

Blecua B., 2001, Las vibrantes del Espańol: manifestaciones acústicas y procesos fonéticos, Unpublished PhD dissertation, Universidad Autonoma de Barcelona, Barcelona.

Carlton L., 1990, Introduction to the Phonological History of the Slavic Languages, Slavica Publishers, Inc., Columbus (Ohio).

Coleman J., 2001, The phonetics and phonology of Tashlhiyt Berber and syllabic consonants, "Transactions of the Philological Society" 99, pp. 29-64.

Dziubalska-Kołaczyk K., 2002, Beats-and-Binding Phonology, Peter Lang, Frankfurt am Main, Berlin.

Gussmann E., 2007, The Phonology of Polish, Oxford University Press, Oxford.

Huntley D., 1993, Old Church Slavonic, [in:] The Slavonic Languages, eds. B. Comrie, G. Corbett, Routledge, London, pp. 125-186.

Jaworski S., 2014, A comparison of Croatian syllabic [r] and Polish obstruentised [r], [in:] New Insights into Slavic Linguistics, eds. J. Witkoś, S. Jaworski, Peter Lang, Frankfurt am Main, pp. 179-192.

Jaworski S., Gillian E., 2011, On the phonetic instability of the Polish rhotic /r/, "Poznań Studies in Contemporary Linguistics" 47 (2), pp. 380-398.

Ladefoged P., 2006, A Course in Phonetics, Thomson Wardsworth, Boston.

Ladefoged P., Maddieson I., 1996, The Sounds of the World's Languages, Blackwell Publishers, Oxford. 
Lindau M., 1985, The story of /r/, [in:] Phonetic Linguistics: Essays in Honor of Peter Ladefoged, ed. V. Fromkin, Academic Press, New York, pp. 157-168.

Moszyński L., 1984, Wstęp do filologii stowiańskiej, Państwowe Wydawnictwa Naukowe, Warszawa.

Recasens D., Espinosa A., 2007, Phonetic typology and positional allophones for alveolar rhotics in Catalan, "Phonetica" 63, pp. 1-28.

Savu C.-F., 2012, An acoustic-phonetic perspective on the phonological behaviour of the rhotic tap, "Proceedings of ConSOLE XX", pp. 213-227.

Schenker A., 1993, Proto-Slavonic, [in:] The Slavonic Languages, eds. B. Comrie, G. Corbett, Routledge, London, pp. 60-123.

Ščukanec A., 2008, Glas r u hrvatskome, njemačkome i engleskome jeziku, "LAHOR: časopis za hrvatski kao materinski, drugi i strani jezik" 1 (5), pp. 66-79.

Shevelov G., 1964. A Prehistory of Slavic. The Historical Phonology of Common Slavic, Universitätsverlag Carl Winter, Heidelberg.

Sievers E., 1881, Grundzüge der Phonetik, Breitkopf and Hartel, Leipzig.

Stieber Z., (1979) 2005, Zarys gramatyki porównawczej języków słowiańskich, Wydawnictwo Naukowe PWN, Warszawa.

Townsend C.E., Janda L., Common and Comparative Slavic: Phonetics and Phonology, Slavica Publishers Inc., Columbus 1996.

Wiese R., 2001, The unity and variation of (German) /r/, "Etudes and Travaux" 4, pp. 11-26.

Wiese R., 2003, The unity and variation of German /r/, "Zeitschrift fur Dialektologie und Linguistik", 70, pp. 25-43.

\section{APPENDIX}

Croatian words containing syllabic rhotics that were used in the study

\begin{tabular}{|l|l|l|}
\hline \multicolumn{1}{|c|}{ \#C_C } & & \multicolumn{1}{c|}{ \#C_C } \\
\hline brbot & rt & brat \\
\hline brdo & rđa & brada \\
\hline brk & rđati & brava \\
\hline brk & rvač & bravar \\
\hline bršljan & rđav & dražba \\
\hline crkva & rzati & brazda \\
\hline crpak & rvanje & draga \\
\hline frka & rt & dragulj \\
\hline grb & rđa & drama \\
\hline grba & rđati & drač \\
\hline grdno & rvač & grad \\
\hline grgeč & rzati & graja \\
\hline krčag & rđav & granit \\
\hline krčma & rđa & trava \\
\hline krk & rvanje & granat \\
\hline
\end{tabular}




\section{Summary}

This article is concerned with the acoustic parameters of the syllabic r-sound of Croatian. The rhotic is regarded as a syllabic nucleus whenever it occupies the inter-consonantal position or one between a pause and a consonant, as in brdo 'hill' and $r t$ 'cape', respectively. The results of the experiment conducted for the purposes of the paper indicate that syllabic rhotics are always pronounced with an epenthetic vowel that is considerably longer than the vocalic element found in consonant-rhotic-vowel sequences, thus the syllabic properties of the rhotic sound, which is typically pronounced as a tap, should be attributed to this vocalic constituent.

Keywords: syllabic rhotics, Croatian, Slavic languages

\section{CECHY AKUSTYCZNE CHORWACKIEGO SYLABICZNEGO [R]}

\section{Streszczenie}

Celem niniejszego artykułu jest przedstawienie cech akustycznych chorwackiego sylabicznego [r]. Choć dźwięk ten należy do grupy spółgłosek, w języku chorwackim jest on również zgłoskotwórczy w słowach, w których [r] nie sąsiaduje z samogłoską, np. brdo 'wzgórze', czy $r t$ 'peleryna'. Wyniki przedstawione w artykule wskazują jednoznacznie, że sylabiczne [r] zawsze wymawiane jest z elementem wokalicznym, który nierzadko jest dłuższy niż nieakcentowane samogłoski w danym wyrazie. Właściwości sylabicznego [r], wymawianego na ogół jako jednouderzeniowa głoska drżąca, należy zatem przypisać protetycznej samogłosce.

Słowa kluczowe: sylabiczne [r], język chorwacki, cechy akustyczne 
